JURNAL PENDIDIKAN USIA DINI

DOI: https://doi.org/10.21009/JPUD.101
DOI: https://doi.org/10.21009/JPUD.101.07

\title{
PERILAKU SOSIAL ANAK USIA DINI DI LINGKUNGAN LOKALISASI GUYANGAN 2016
}

\author{
FAJAR LUQMAN TRI A. \\ PAUD PPs Universitas Trunojoyo Madura \\ Jl. Raya Telang, Madura. E-mail: fajarluqman1991@gmail.com
}

\begin{abstract}
This research aimed to describe the social behavior of children aged 5-6 years in the Localization Guyangan Bagor Nganjuk District of East Java. The study was conducted to early childhood schooling in kindergarten Pertiwi Guyangan village. There are three main subfokus studied were the first form of social behavior, the process of internalization, and three factors supporting and inhibiting the formation of social behavior. The study used a qualitative approach to the type of case study method. Analysis of the data used that model of Miles and Huberman with data collection techniques using observation, interviews, and documentation. Subjects The study focused on children aged 5-6 years amounted to two people. The results showed a positive form of social behavior that develops between the two subjects, namely research cooperation, generosity, caring and adaptable to new people. There was also a negative social behavior is the behavior of the authorities, the dependency will love the attention of others and antagonism of the sexes. The process of internalizing social behavior of which is formed through gift giving, the punishment and the process of imitation. Parenting applied by parents is the subject of research using authoritarian and permissive parenting style is accompanied by violence in applying the rules.
\end{abstract}

Keywords: social behavior, early childhood, localization

\begin{abstract}
Abstrak : Penelitian ini bertujuan untuk mendeskripsikan perilaku sosial anak usia 5-6 tahun di lingkungan Lokalisasi Guyangan Kecamatan Bagor Kabupaten Nganjuk Jawa Timur. Penelitian dilakukan kepada anak usia dini yang bersekolah di TK Pertiwi Kelurahan Guyangan. Ada tiga subfokus utama yang diteliti yaitu pertama bentuk perilaku sosial, kedua proses internalisasi, dan ketiga faktor penunjang serta penghambat pembentukan perilaku sosial. Penelitian menggunakan jenis pendekatan kualitatif dengan metode studi kasus. Analisis data yang digunakan yaitu model Miles dan Huberman dengan teknik pengumpulan data menggunakan observasi, wawancara, dan dokumentasi. Subjek Penelitian difokuskan pada anak usia 5-6 tahun yang berjumlah dua orang. Hasil penelitian menunjukan bentuk perilaku sosial positif yang berkembang diantara kedua subjek penelitian yaitu kerjasama, kemurahan hati, kepedulian dan mudah beradaptasi dengan orang baru. Selain itu ada juga perilaku sosial negatif yaitu perilaku penguasa, ketergantungan akan kasih sayang perhatian orang lain dan antagonisme jenis kelamin. Proses internalisasi perilaku sosial diantaranya terbentuk melalui pemberian hadiah, hukuman dan proses imitasi. Pola pengasuhan yang diterapkan oleh orang tua
\end{abstract}


JURNAL PENDIDIKAN USIA DINI

Volume 10 Edisi 1, April 2016

subjek penelitian menggunakan gaya pengasuhan otoriter dan permisif disertai dengan kekerasan dalam menerapkan aturan.

\section{Kata Kunci : perilaku sosial, anak usia dini, lokalisasi}

Anak usia dini dilahirkan di dunia dengan sejuta rasa ingin ingin tahu yang tinggi serta mengimitasi apa saja yang dilakukan oleh orang disekitarnya yang dirasa menarik. Hal tersebut menjadikan betapa besarnya peran lingkungan sekitar dalam memberikan kontribusi pada pembentukan perilaku sosial anak. Mengarahkan perilaku sesuai keinginan lingkungan memegang peranan penting, agar anak tidak salah dan terjerumus kedalam perilaku anti sosial atau perilaku yang tidak diterima lingkungan ketika beradaptasi di masyarakat. Ketika anak membangun hubungan dengan orang lain, secara tidak langsung anak melewati peristiwa-peristiwa yang sangat bermakna dalam sejarah kehidupannya. Peristiwa tersebut akan terekam baik di memori anak seiring berjalannya usia. Mengajarkan perilaku prososial pada anak sedini mungkin, akan membawa dampak yang posiitif dan melekat pada pribadi anak, sampai anak kelak tumbuh dan berkembang menjadi dewasa bahkan sampai menua.

Perilaku sosial berhubungan erat pada perilaku anak dalam menyesuaikn diri dengan aturan-aturan masyarakat di lingkungan sekitar. Perilaku sosial diperoleh anak melalui kematangan dan kesempatan belajar dari berbagai stimulus yang diberikan lingkungannya. Tatanan lingkungan sosial yang baik dan sehat dapat membantu anak mengembangan konsep dalam diri anak yang positif serta mendukung proses sosialiasi menjadi optimal. Kesuksesan tujuan tersebut tidak mungkin terjadi begitu saja tanpa ada keterlibatan dari anggota keluarga, sekolah, dan lingkungan masyarakat di sekeliling anak.

Melalui rangsangan atau
stimulus yang tepat dan sesuai
perkembangan anak, akan membantu


Perilaku Sosial ...

Fajar Luqman Tri

anak siap dalam memasuki tahapan perkembangan selanjutnya dengan baik. Keluarga adalah tempat pertama bagi anak untuk mendapatkan pendidikan dan kasih sayang. Orang tua merupakan pendidik pertama dalam hidup anak, maka peran keluarga dalam mengasuh anak memegang peranan utama. Sesuai dengan Undang-Undang Hak dan Kewajiban Orang Tua Pasal 7 bahwa orang tua berhak berperan serta dalam memilih satuan pendidikan dan memperoleh informasi tentang perkembangan pendidikan anaknya. Di keluarga anak memiliki waktu yang sangat lama dibandingkan di lingkungan luar rumah. Orang tua sangat memegang peran penting dalam pembentukan perilaku anak, agar dapat menjadi bekal di kehidupannya mendatang.

Pengasuhan yang diberikan dan diterapkan oleh orang tua akan sangat mempengaruhi tumbuh kembang dan keberhasilan anak pada perkembangan selanjutnya, mulai dari kepribadian, mental, moral, sosial dan spiritualnya. Oleh sebab itu, peranan orang dewasa yaitu orang tua sangat penting bagi perkembangan anak. Keberhasilan semua aspek perkembangan anak sangat bergantung pada lingkungan kehidupan anak. Selain keluarga, lingkungan sekolah memiliki peran yang sama dalam pembentukan perilaku anak. Tugas sekolah selain memberikan ilmu dan wawasan bagi anak, juga berperan dalam membentuk perilaku antara lain perilaku sopan santun, budi pekerti yang baik, empati, simpati, kemurahan hati dan membangun sosialiasi dengan kawan sebaya di sekolahnya. Sekolah merupakan salah satu sarana untuk mewujudkan impian tujuan pendidikan nasional. Disamping itu lingkungan sekitar rumah juga memiliki peluang besar untuk terjadi penyimpangan perilaku. Hal tersebut disebabkan karena anak tidak mengetahui bagaimana sikap dan perilaku yang baik sesuai dengan norma-norma yang berlaku. Hal itu bukan kesalahan anak karena pada dasarnya anak sudah diwarisi karakter meniru, apa yang dia lihat dan melakukan apa yang dia ketahui akan dia terapkan dalam 
kehidupan sehari-hari. Namun ketika anak telah memiliki dasar atau fondasi yang baik, maka anak akan mengerti mana hal yang baik yang harus dia lakukan dan mana hal buruk yang tidak boleh dilakukan.

Perilaku baik atau buruk yang terjadi pada anak tergantung bagaimana orang dewasa dalam hal ini orang tua, pendidik dan orang di sekitar rumah dalam menerapkan serta memberikan simulasi yang baik serta patut ditiru oleh anak. Perilaku tersebut akan dibawa anak untuk menghadapi kehidupan selanjutnya, yaitu ketika anak masuk pada lingkungan masyarakat yang lebih luas dan ketika anak memasuki tahapan selanjutnya, sehingga akan melekat dan tertanam dalam kepribadian anak. Lingkungan masyarakat atau lingkungan diluar tempat tinggal anak adalah salah satu tempat keseharian yang dihabiskan oleh anak ketika anak sudah selesai dari ativitas sekolah dan aktivitas di rumah. Peran lingkungan masyarakat juga tidak kalah penting dibandingkan dengan peran keluarga dan peran disekolah. Ketika anak berada diluar rumah dan di luar sekolah peran masyarakat sekitar mmemiliki wewenang besar untuk menstimulasi perkembangan anak. Lingkungan yang baik akan menjadikan masyarakat dilingkungannya menjadi baik begitu dengan sebaliknya. Anak akan mengikuti dan menuruti segala aturan yang menjadi pedoman dalam kehidupan sehari di lingkungan tersebut.

\section{Perilaku Sosial Anak Usia 5-6 Tahun}

Menurut Mulyasa (Mulyasa, 2012:26) anak usia dini adalah inidividu yang sedang mengalami proses pertumbuhan dan perkembangan yang sangat pesat, bahkan dikatakan sebagai lompatan perkembangan.

\section{Sujiono (Sujiono, 2012:6)} menambahkan bahwa anak usia dini adalah sosok individu yang sedang menjalani proses perkembangan yang pesat dan fundamental untuk kehidupan selanjutnya.

Dari beberapa pendapat di atas dapat disimpulkan bahwa anak usia dini adalah individu yang berada pada 
Perilaku Sosial ...

Fajar Luqman Tri

rentang usia 0-8 tahun dimana

activities can influence the bermuaranya seluruh aspek environment, the environment can perkembangan kognitif, fisik, dan change the person's cognition, and so sosial emosional yang berpengaruh terhadap perkembangannya kedepan.

Hurlock

(1992:155-156)

berpendapat pada usia 5-6 merupakan

usia berkelompok, Anak ingin bersama teman-temannya dan akan merasakan kesepian serta tidak puas bila tidak bersama teman-temannya. Menurut Suntrock (2007:19) proses sosial emosi melibatkan perubahan dalam hubungan seseorang dengan orang lain, perubahan emosi, dan perubahan dalam kepribadian. Menurut Mulyasa (2012;30) perilaku sosial atau non sosial yang dibina pada awal masa kanak-kanak akan sangat menentukan kepribadiannya, baik melalui pengalaman yang menyenangkan maupun tidak menyenangkan, berupa hubungan dengan anggota keluarga atau dengan orang-orang diluar keluargaa.

Bandura (Santrock, 2007:50) menyatakan bahwa "Behavior can influence person/ cognitive factors and vice versa. The person's cognitive on". Hal ini menyatakan bahwa perilaku dapat mempengaruhi seseorang, ada korelasi antara perilaku seseorang dengan lingkungan, baik kognitif terhadap lingkungan, maupun sebaliknya hingga seterusnya. Dalam hal ini lingkungan yang dimkasud adalah tempat dimana anak berada, oleh karena itu perolehan kemampuan berprilaku sosial tersebut melibatkan komponen keluarga, sekolah dan masyarakat.

Pavlov (Santrock, 2007:52) menyatakan bahwa perilaku didasari dari pola kebiasaan, hal ini ia buktikan dari risetnya di awal tahun 1900an, dari hasil riset tersebut membuktikan bahwa pola kebiasaan memberi pengaruh besar terhadap perilaku. Kebiasaan-kebiasaan dalam kehidupan sehari-hari yang berupa tindakan merupakan bentuk dari perilaku.

Hurlock (2007: 262-265) Adapun pola perilaku sosial anak usia 5-6 tahun yaitu Kerja sama, persaingan, kemurahan hati, hasrat 
akan penerimaan sosial, simpati, empati, ketergantungan, sikap ramah, sikap tidak mementingkan diri sendiri, meniru, perilaku kelekatan (attachment behavior),

Dari beberapa pendapat teori diatas dapat ditarik kesimpulan bahwa perilaku sosial adalah tindakan interaksi antar individu dalam mebangun hubungan yang saling berkaitan, dan perilaku sosial individu dipengaruhi oleh berbagai faktor, yang paling dominan adalah faktor lingkungan atau budaya dimana individu itu berada, berdampak pada pola kebiasaan yang lama-lama menjadi ciri khas suatu perilaku dari individu tersebut.

\section{Keluarga}

Menurut Cox dan Paley (Santrock, 2007:158), bahwa keluarga adalah subsistem-subsistem dimana didalam subsistem itu ada komponen ayah, ibu, dan anak-anak. Hubungan subsistem tersebut dapat mempengaruhi keharmonisan dan berujung pada pengasuhan yang mengahsilkan kebahagiaan.
Santrock

(2007:157)

mengemukakan setiap keluarga adalah "suatu sistem-suatu kesatuan yang dibentuk oleh bagian-bagian yang saling berhubungan dan berinteraksi. Hubungan tidak pernah hanya beralngsung satu arah".

Hurlock

menyatakan hubungan keluarga mempengaruhi penyesuaian diri secara sosial di luar rumah. Pengaruh yang mendalam dari hubungan anak dengan keluarga jelas terlihat dalam berbagai bidang kehidupan, oleh sebab itu keluarga berperan penting dalam pembentukan kepribadian.

Papalia (2014:1.24) dalam modul psikologi perkembangan anak menyatakan bahwa:

Ada dua bentuk susunan keluarga yang umum ditemukan, yaitu nuclear-family dan extended family. Nuclear-family atau keluarga inti/keluarga batih dapat diartikan sebagai unit rumah tangga yang terdiri dari satu atau dua orang tua dan anak-anak mereka, baik anak biologis, anak adopsi, atau anak tiri. 
Perilaku Sosial ...

Fajar Luqman Tri

Bentuk kelurga seperti ini dominan dalam masyarakat barat. Extended-family atau keluarga besar merupakan jaringan hubungan multigenerasi yang terdiri dari kakeknenek, paman-bibi, sepupu dan saudarasaudara yang lebih jauh hubunganngya.

Dari beberapa definisi diatas dapat disintesiskan bahwa keluarga adalah bagian dari kehidupan individu dimana menjadi tempat untuk memperoleh perlindungan, kasih sayang, interaksi, dan pendidikan.

\section{Pola Pengasuhan}

Santrock (2007:8) menyatakan "Reletionship with family members and parenting are important influences on children's development", ia berpendapat bahwa hubungan antara anggota keluarga dan pola pengasuhan sangat penting dalam mempengaruhi perkembangan anak, selain itu Suntrock (2007:11) juga berpendapat bahwa pengasuhan adalah bagaimana cara menentukan sikap dalam mengatur anak. Yaitu secara permisif atau otoriter.
Elizabeth Hurlock (2007:205) mengungkapkan pola pengasuhan sebagai metode yang dipilih orang tua sebagai metode pendidikan anak. Dibagi menjadi tiga yaitu pola pengasuhan otoriter, permisif, dan demokratis. Adapun ciri dari masingmasing pola tersebut adalah Pola Pengasuhan Otoriter, Pola Pengasuhan Demokratis, Pola pengasuhan Permisif.

Menurut Baumrind (Hurlock, 2007:205-215) ada empat jenis gaya pengasuhan yaitu pengasuhan otoritarian, pengasuhan otoritatatif, pengasuhan mengabaikan, pengasuhan menuruti.

Dari beberapa definisi diatas dapat disintesiskan bahwa pola pengasuhan adalah cara yang diterapkan orang oleh tua kepada anaknya dalam proses menumbuhkembangkan anak/membesarkan anaknya, secara garis besar dibagi menjadi tiga, yaitu permisif, demokratis, dan otoriter.

\section{Proses Internalisasi Perilaku Sosial}

Bandura (Santrock, 2012: 30) adalah arsitek utama dari teori kognitif sosial yang menjelaskan bahwa proses- 
proses kognitif memiliki kaitan penting dengan lingkungan dan perilaku.

Bandura (Crain, 2014:302) berpendapat bahwa dalam situasisituasi sosial, manusia sering kali belajar jauh lebih cepat hanya dengan mengamati tingkah laku orang lain. Sebagai contoh ketika anak-anak belajar lagu baru atau bermain rumahrumahan meniru sikap orang tua, maka mereka sering memproduksi secara instan urutan panjang tingkah laku baru. Mereka memperoleh sebagian besar segmen tingkah laku baru hanya melalui pegamatan.

(Wahyudi, 2005:89) Orang tua juga berperan sebagai guru, anak belajar banyak dengan melihat apa yang orang tua lakukan. Tanpa disadari cara orang tua berinteraksi dengan orang lain dicermati oleh anak. Orang tua bisa membantu memahami cara berhubungan dengan orang lain dengan memberikan contoh langsung, membiarkan anak memperhatikan bagaimana perubahan cara bicara juga gerak tubuh saat sedang berhadapan dengan orang lain. Ajak anak bersama ke berbagai kesempatan yang memungkinkan anak bisa bertemu banyak orang, dan terbiasa dengan keramaian.

Dari beberapa sumber diatas dapat dismpulkan bahwa dengan mengamati dan meniru adalah cara yang cepat bagi anak untuk belajar berperilaku di lingkungan. Anak mengamati dan menirukan perilaku yang ada disekitarnya. Perilaku baik atau buruk adalah cerminan dari lingkungan yang diterapkan oleh anak.

\section{Lingkungan Lokalisasi}

(Saptari, 1997:197) Lokalisasi adalah suatu tempat yang menyediakan jasa portitusi atau pelacuran dimana dalam aktivitasnya bertujuan pada seksual atau perzinaan. Ratna saptari menjelaskan bahwa prostitusi adalah suatu transaksi antara perempuan pelacur dan lelaki hidung belang yang member sejeumlah uang untuk berintereksi seksual.

Bagong Suyanto (Suyanto, 2013:159) menambahkan bahwa portitusi atau pelacuaran adalah suatu praktik hubungan seksual sesaat, yang 
kurang lebih dilakukan dengan siapa saja, untuk imbalan berupa uang.

Berdasarkan

beberapa

pemaparan diatas dapat ditarik

kesimpulan bahwa Lokalisasi adalah

lingkungan atau tempat dimana

berkumpulnya aktivitas prostitusi atau

pelacuran yang menyedikan jasa

seksual antara dua individu yang saling

membutuhkan. Lokalisasi tercipta atau

hadir karena adanya kebutuhan

ekonomi dan praktek kepuasan seksual

dalam kehidupan sehari-hari.

Beberapa hasil penelitian yang relevan dengan penelitian ini, Glen Dunlop dan Dinane Powell dengan judul Promoting social behavior of Young Childeren in Group Setting. Pada penelitian ini melihat anak-anak lintas budaya yang dibangun kolaborasainya untu perkembangan dengan teman sebaya, perbedaan dengan penelitian yang dilakukan yaitu penelitian perilaku sosial lebih melihat bentuk perilaku sosial, proses interlailsasi dan faktor penunjag dan penghambat perilaku sosial. Kenneth H. Rubin dan Meliss Menzer dengan judul Culture dan Social Development dimana pada penelitian melihat dan mengamati perilaku sosial anak yang ada dikelas. Perbedaan dengan penelitian yang diteliti yaitu pada subjek dan lingkungan penelitian serta metode yang digunakan. Nopa Wilyanita dengan judul perilaku Sosial Anak di Kampung Nelayan yang dalam penelitiannya mendiskripsikan perilaku sosial anak di kampung Nelayan. Persamaan dengan penelitian yang diteliti sama-sama melihat perilaku sosial. tetapi berbeda dengan penelitian yang diambil yaitu pada metode dan subjek serta tempat dilakukannya penelitian.

Esti Kurniawati, pada penelitiannya dengan judul "Peningkatan Perilaku Sosial Melalui Permainan Tradisional Jawa". Keterkaitan antara penelitian tersebut dengan penelitian ini adalah samasama meneliti tentang perilaku sosial tetapi pendekatan yang digunakan berbeda. Selanjutnya Mansyur Romadon Putra dengan judul "Pengasuhan anak usia 5-6 tahun di Kampung Tapak Lebar Sumatera selatan". Kesamaan dengan penelitian 
ini adalah sama-sama menggunakan pendekatan kualitaitf membahas tentang pola kehidupan anak usia dini pada suatu komunitas daerah tertentu, perbedaannya adalah penelitian lebih menggunakan studi kasus dan lebih mendalami permasalah perilaku sosial anak

\section{Metode Penelitian}

Metode yang digunakan dalam penelitian ini adalah Studi kasus dengan pendekatan penelitian kualitatif yang bertujuan untuk meneliti kondisi objek yang alamiah, peneliti sebagai instrumen kunci, teknik pengumpulan data dilakukan secara triangulasi, analisis data bersifat induktif, dan hasil penelitian kualitatif lebih menekankan makna daripada generalisasi (Sugiyono, 2007: 1-3). Sumber-sumber data dari penelitian ini adalah, antara lain : subjek penelitian, warga sekolah TK Pertiwi Kelurahan Guyangan, keluarga subjek penelitian, dan warga lingkungan lokalisasi Guyangan. Penelitian adalah anak usia 5-6 tahun. Lokasi sosial dalam penelitian ini adalah kelurahan Guyangan kecamatan Bagor Kabupaten Nganjuk.

Teknik pengumpulan data pada penelitian ini menggunakan pengamatan langsung, wawancara mendalam dan dokumentasi terkait dengan pengasuhan anak. Teknik analisis data menggunakan model Milles dan Huberman dengan tiga tahapan yaitu reduksi data dilanjutkan dengan penyajian data dan diakhiri dengan penarikan kesimpulan.

\section{HASIL DAN PEMBAHASAN}

Berdasarkan hasil pembahasan yang telah dilakukan pada bab sebelumnya, maka menghasilkan kesimpulan sebagai berikut:

Perilaku sosial yang ada pada diri anak adalah hasil dari produk lingkungan dimana individu berada. Keluarga, teman sebaya, lingkungan sekolah dan masyarakat sekitar adalah pembentuk dan pendukung terbentuknya perilaku pada diri anak. perilaku sosial kerjasama terbentuk karena adanya indvidu lain yang melakukan hal yang sama, seperti bermain dengan tujuan bersama, saling 
berkompromi ketika ingin mengadakan permainan, dan mampu membagi tugas sesuai porsinya secara tidak langsung kerjasama akan terbentuk pada diri anak. semakin banyak teman ketika usia dini maka semakin mudah anak memiliki perilaku kerjasama. kepedulian pada orang lain ada karena kelekatan antara individu dengan orang lain. Semakin banyak anak melakukan kontak bermain, maka semakin dekat kedekatan emosi anak untuk saling peduli satu sama lain.

Mudah bergaul atau akrab dengan orang baru terbentuk karena kebiasaan yang terjadi sehari-hari. Terbiasa kontak dan komunikasi dengan orang baru membuat anak menjadi terbiasa dan tidak takut mengalami atau mendapatkan kehadiran orang baru pada situasi yang baru. Kemurahan hati pada orang lain disebabkan oleh pembiasaan yang dilakukan oleh orang disekitar anak sehingga anak mampu meniru dan melakukan hal tersebut dan di praktekan kepada orang lain. Salah satu cara memperoleh persetujuan sosial adalah membagi kepunyaannya seperti mainan yang dimilikinya. Pada saat tertentu anak juga rela membagi makanan kepada anak lain agar dapat mempertebal pertememanan mereka dan menunjukan identitas keakraban antar individu.

Meniru adalah salah satu karakter yang dimiliki anak usia dini termasuk anak usia 5-6 tahun. Menirukan segala tingkah laku yang baru dilihat secara berulang-ulang dan dirasa hal tersebut menarik perhatian anak secara tidak langsung akan terekam sendirinya dalam pikiran anak Sehingga ketika mengalami permasalahan atau terlibat dengan kejadian yang sama, maka anak akan menirukan perbuatan yang dilihat sebelumnya. Memberikan hadiah ketika anak berperilaku baik menambah rasa percaya diri anak untuk mengulangi hal tersebut dan menjadikan motivasi tersendiri pada diri anak. Sama halnya dengan memberikan hukuman mengisyaratkan pada anak bahwa perilaku yang dilakukan itu buruk.

Peraturan yang diterapkan oleh orang tua seperti pembatasan atau 
kebebasan saat bermain atau pembolehan berteman dengan anak tertentu dapat membantu mengekang atau mencegah munculnya perilaku yang tidak dinginkan. Mengondisikan benda yang awalnya tidak memiliki fungsi yang tidak menakutkan bisa menjadikan menakutkan ketika benda tersebut memberi dampak pada anak saat melakukan kesalahan atau melanggar suatu peraturan yang sudah ditetapkan. Lingkungan disekitar anak memegang peranan penting dalam menunjang dan menghambat perilaku sosial anak. Lingkungan keluarga memiliki peranan dominan ketika anak berada dirumah, gaya pengasuhan orang tua seperti otoriter membuat anak menjadi takut untuk melakukan hal diluar perintah orang tua, kekerasan dalam mendidik anak seperti memukul dengan sapu atau benda lainnya membuat anak tidak berani dan selalu kawatir saat bermain bersama temannya atau melakukan aktivitas sesuai keinginnya sendiri. Ketika anak berada diluar rumah anak akan merasa bebas dan tidak ada beban untuk bisa bermain tanpa ada rasa kawatir dan hukuman dan merasa terbebas dalam waktu sejenak.

Pengasuhan gaya permisif menjadikan anak merasa bebas melakukan semua keinginan yang dimaunya ketika berada dirumah tanpa ada rasa takut hukuman dan aturan yang mengikat saat bermain di lingkungan sekitar rumah, gaya pengsuhan tersebut menjadikan orang tua memberi kebebasan tanpa kontrol tidak mempersalah anak bermain dengan siapaun dan bermain sampai kapanpun. Sekolah. Menanamkan perilaku sosial saat disekolah adalah salah tujuan tercapainya pembelajaran. Mau bermain bersama teman, bekerjasama dengan temannya, saling berbagi peduli dengan temannya adalah beberapa hal yang bisa dilakukan ketika di sekolah. Lingkungan yang buruk seperti lingkungan lokalisasi tidak selamanya menjadikan anak memiliki perilaku buruk, pengontrolan orang tua, peran sekolah dan masyarakat sekitar dapat membantu membimbing dan mengarahkan anak kepada perilaku prososial. Pembatasan jam bermain 
dan membuat aturan yang yang keras dapat membentuk anak untuk berperilaku sesuai keingin keluarga dan sekolah.

Memiliki teman sebaya pada usai 5-6 tahun adalah hal terpenting yang dibutuhkan anak, dengan teman sebaya memberikan pengalaman belajar pada anak yang tidak bisa mereka dapatkan dengan cara yang lain. Bersama dengan teman sebaya anak menjalin persahabatan, hubungan khusus dengan ditandai dengan kelekatan dan minat bersama saat bermain, berkompromi membuat aturan dan bermain bersama dengan teman sebaya adalah kegiatan yang menarik untuk dilakukan. Teman sebaya membawa dampak pada aktualisasi perilaku sosial anak. semakin banyak anak melakukan kontak dengan teman sebaya maka semakin mudah anak membentuk perilaku sosial. teman sebaya adalah bukti penerimaan individu dapat diterima dilingkungannya.

\section{SIMPULAN}

Berdasarkan hasil pembahasan yang telah dilakukan pada bab sebelumnya, maka ditarik kesimpulan sebagai berikut :

1. Perilaku sosial anak lingkungan lokalisasi usia 5-6 tahun yang bersekolah di TK Pertiwi dominan kearah perilaku sosial seperti kerjasama, kemurahan hati kepedulian dan bentuk perilaku antisosial seperti penguasa dan pilih-pilih dalam berteman.

2. Pengasuhan yang diterapkan orang tua terhadap anak-anak dominan otoriter dan permisif disertai dengan kekerasan

3. Pemberian hadiah, hukuman dan proses imitasi membantu anak untuk menumbuhkan perilaku sosial anak.

\section{DAFTAR PUSTAKA}

Crain, William, Teori Perkembangan Konsep dan Aplikasi. Terjemah Yudi Susanto Yogyakarta: Pustaka Pelajar, 2007.

CHA, Wahyudi, Progam Pendidikan untuk Anak Usia Dini di 
Prasekolah Islam, (Jakarta:

Grasindo, 2005)

Hurlock, Perkembangan Anak Jilid 1 Alih Bahasa Meitasari Tjandrasa. Jakarta : Erlangga, 2007. Elizabeth, Perkembangan Anak. Jakarta: Erlangga, 1996.

Elizabeth. Psikologi Perkembangan Suatu Pendekatan Sepanjang RentangKehidupan

terjemahan Istiwidayanti dan Soedjarwo .Jakarta: Erlangga, 1992

Morrison, George S, (Alih bahasa suci Romadhona), Dasar-dasar Pendidikan Anak Usia Dini, Edisi ke Lima .Jakarta:Indeks, 2012.

Mulyasa, Manajemen PAUD, Bandung: PT. Remaja Rosdakarya, 2012.

Papalia, Diane E. dan Sally Wendkos Olds, A Child's World Infancy Through
Adolescence .United States of America: McGRAWHILL, 1990.

Santrock, John W. Children ninth Edition. America : Mc Graw Hill, 2007. , John W. perkembangan anak Jilid 1 Alih bahasa Mila Rachmawati dan Anna Kuswanti. Jakarta : Erlangga, 2007.

John W. Perkembangan Anak Jilid 2 Terjemahan Mila Rachmawati dan Anna Kuswanti .Jakarta: Erlangga, 2007.

Saptari, Ratna, Perempuan Kerja dan Perubahan Sosial Sebuah Pengantar Studi Perempuan. Jakarta: Kalyanamitra, 1997.

Suyanto, Bagong, Masalah Sosial Anak (Jakarta: Kencana Prenada Media Group, 2013).

Sugiyono, Memahami Penelitian Kualitatif (Cet Bandung:Alpabeta, 2007) 